\title{
ZBTB38 Gene
}

National Cancer Institute

\section{Source}

National Cancer Institute. ZBTTB38 Gene. NCI Thesaurus. Code C99620.

This gene plays a role in transcriptional regulation. 